Dhaka Univ. J. Biol. Sci. 28(2): 139-146, 2019 (July)

\title{
SELF-ESTEEM AND COPING SKILLS OF VICTIMS AND NON-VICTIMS OF BULLYING IN PUBLIC SCHOOL
}

\author{
ISHRAT SHAHNAZ* AND HOSNE ARA \\ Department of Psychology, University of Dhaka, Dhaka-1000, Bangladesh
}

Key words: Bullying, Self-esteem, Coping skills

\begin{abstract}
Good self-esteem and coping skills are essential to maintain a strong, happy and healthy life. The present study examined the self-esteem and coping skills of victims and non-victims of bullying in public school. The sample consisted of 150 participants (75 bullied and 75 non-bullied) who were selected through convenience sampling technique from different public schools of Dhaka city. The Bangla version of the California bullying victimization scale, the Rosenberg's self-esteem scale and the coping scale were used to achieve the research objectives. Result of the study showed that bullying was negatively correlated with self-esteem and coping skills whereas self-esteem was positively correlated with coping skills. Result also showed that there were significant differences in self-esteem and in coping skills between victims and non-victims of bullying. The findings of the present study will advance our understanding about the negative impact of bullying on children's mental health and will help mental health professionals to develop bullying awareness program for teachers and parents.
\end{abstract}

\section{Introduction}

Many children and adolescents experience a number of emotional and social difficulties in the process of growing up. Difficulties in peer relationships are associated with negative change in self-concept and feeling of self-worth that may impair school adjustment ${ }^{(1-2)}$ and bullying is one of the common maladaptive types of peer interaction among elementary and middle school students.

Bullying is a universal phenomenon that is affecting school aged children around the world. It is a conscious, and intentional aggressive action planned to hurt, bring distress, and create terror ${ }^{(3)}$. Eighty six per cent of children aged 12 to 15 years reported being bullied at school(4). However sometimes it goes unreported and when it is unreported, victim's self-esteem and coping ability become gradually poor ${ }^{(5)}$.

Bullying can occur to any person regardless of their age, gender, class, race, sexual orientation, national origin or any other background factor and no blends of personalities can give surety that a child will or will not become the victim of bullying. Victims of

\footnotetext{
*Author for correspondence: <ishahnaz.psy@du.ac.bd>.
} 
bullying display some common characteristics, such as shyness, inwardness, low selfconfidence, sadness and anxiety. They are often insecure, depressed and engage in suicidal ideation much more often than their peer(6).

Bullying is a kind of youth violence which intimidates young people's development. Families and friends are frequently facing the detrimental effects of bullying and the overall wellbeing and security of schools, neighborhoods, and societies are at risk. It has a harmful effect on school functioning, physical health, self-perception and academic achievement ${ }^{(7-9)}$. Anxiety, depression, low self-esteem, psychometric symptoms were most common in victims of bullying and bullies as well(10). In the most severe cases, the victims of bullying fall of severe depression and engage in suicidal behavior ${ }^{(11)}$.

Bullying to children can happen any place, but it commonly occurs at or near school spaces where adult observation is restricted or non-existent (e.g. entrances, lobbies, canteens, play area, buses, locker rooms, and classrooms). Bullying by peers associates with sicknesses, school avoidance, poor academic performance, increased fear and anxiety, and suicidal ideation as well as to long-term internalizing complications involving low self-esteem, anxiety, and depression ${ }^{(12-13)}$.

There are many forms of bullying. The four common types are physical bullying, verbal bullying, social bullying and cyber bullying. Electronic aggression, or "cyber bullying", has now become very common. While physical, verbal or social bullying usually take place at school premises or work, cyber bullying occurs over internet. Similar to physical bullying, cyber bullying also targets youth societies, such as children and teenagers. Cyber bullying can produce severe psychological damages in victims ${ }^{(14-15)}$. Violence in school can affect students' self-esteem level. Children who have low selfesteem are more prone to victimization by bullies whereas bullies tend to have high selfesteem $^{(16)}$. Agatston et al. ${ }^{(17)}$ found that cyber bullying reduces people's coping skills and self-esteem. It damages our positive self-esteem and stimulate us to attempt suicide( ${ }^{(14)}$.

Coping and self-esteem are positively correlated. The person whose self-esteem is high has also high coping skills ${ }^{(18)}$. Bullying can damage our coping capability ${ }^{(5,19-20)}$. Bullying victims develop depression, low self-esteem, and low coping skills whereas non-victims have higher coping skills than victims of bullying ${ }^{(21)}$.

There are many ways to cope with bullying. Prior evidence suggests that some students ask friend's advice, seek adult's help, report the occurrence to a teacher or ignore it and walk away to cope with bullying(22-24). According to Lazarus et al.(25-26), there are two main functions of coping : either it creates stress by altering the problems or it regulates the emotional response to the problem. Maladaptive coping results in emotional maladjustment, passive avoidance, cogitation and termination, substance abuse, and depressed educational attainment ${ }^{(27)}$.

The present research was done to see the association between self-esteem and coping skills of victims and non-victims of bullying in public schools in Bangladeshi context 
because the number of bullying behaviors are increasing day by day and affecting the school aged children's wellbeing and social functioning(28). This research can be a valuable source of information about the mental state of bullying victims for others to pursue more research in future.

The objective of the present study was to see the relationship of bullying with selfesteem and coping skill. The study also investigated whether there were any differences in self-esteem and in coping skills between victims and non-victims of bullying.

\section{Materials and Methods}

One hundred and fifty students were selected conveniently as study participants from different public schools in Dhaka city. Among them 74 (49.33\%) were boys and 76 $(50.67 \%)$ were girls. They were also divided into victims (50\%) and non-victims (50\%) of bullying. They were students of class five to class eight and their age ranged from 12 to 14 years.

The following instruments were used to collect data:

California bullying victimization scale (CBVS): Bangla version of The California bullying victimization scale(29), originally developed by Felix et al.(30) was used to asses bullying victimization among elementary and middle school. The CBVS include eight items related to bullying victimization behavior, and it is a five point scale $(0=$ Never, $1=$ Once in the past month, $2=2$ or 3 times in the past month, 3 = about once a week, and $4=$ several times a week). The test-retest reliability for Bangla version was found to be. 80 and internal consistency was $0.80^{(29)}$.

Coping scale: The scale was originally developed by Folkman and Lazarus (26) and was adapted by Huque(31). The scale consists of 22 items. The measure is 4 point Likert type scale with 1 (I usually don't do this), 2(I usually do this sometimes), 3 (I do most of the time), 4 (I do this always). Highest score of the scale is 88 and the lowest score is 22 . The reliability of the coping scale was reported to be highly significant $(\mathrm{r}=0.86)$, and the testretest of each subscale was also reported highly significant $(\mathrm{r}=0.80)^{(31)}$.

Rosenberg's self-esteem scale: An adapted Bangla version of Rosenberg self-esteem scale was used ${ }^{(32)}$. The scale was originally developed ${ }^{(33)}$ to measure adolescent's feeling of self-worth or self-acceptance. Ii is a ten item Likert type scale with four point response format (strongly agree, agree, disagree, strongly disagree). The scale ranges from $10-40$ with higher score representing higher self-esteem. Five items estimate positive feelings and five items estimate negative feelings about self. Items 3, 5, 8, 9, 10 are reversed scored. The test-retest correlations are typically in the range of 0.82 to 0.88 , and Cronbach alpha for various samples are in the range of 0.77 to $0.88^{(32)}$.

After taking permission from the school authority and getting informed consent from the participant, the questionnaires were given to each participant individually. Although 
the questionnaires contained written instruction, the students were given extensive verbal instruction to further clarify the task and the meaning of some of the items. They were also required not to omit any item in the questionnaire. They were assured that the data would be kept confidential and would be used only for research purpose. After accomplishment of their task, the answered questionnaires were collected from them and they were given thanks. It took four weeks to collect all the data. Data were analyzed in Pearson product moment correlation and $\mathrm{t}$ test.

\section{Results and Discussion}

The aim of the present study was to investigate the self-esteem and coping skills between the victims and non-victims of bullying. For this purpose the obtained data were analyzed by correlation and $\mathrm{t}$ test.

Table 1. The correlation of bullying with self-esteem and coping skills.

\begin{tabular}{lccc}
\hline Variables & 1 & 2 & 3 \\
\hline 1. Bullying & 1 & & \\
2. Self-esteem & $-0.822^{* *}$ & 1 & \\
3. Coping skills & $-0.829^{* *}$ & $0.996^{* *}$ & 1 \\
\hline
\end{tabular}

$* * 0<0.01$.

Table 1 shows that bullying has significant and negative correlations with self-esteem $(\mathrm{r}=-0.822)$ and coping skills $(\mathrm{r}=-0.829)$, and self-esteem has a significant and strong positive correlation with coping skills $(r=-0.996)$.

Table 2. The mean, standard deviation and $t$ value of the self-esteem between the victims and non-victims of bullying.

\begin{tabular}{lcccccc}
\hline Bullying & $\mathrm{N}$ & $\mathrm{M}$ & $\mathrm{SD}$ & $\mathrm{t}$ & $\mathrm{df}$ & $\mathrm{P}$ \\
\hline Victims & 75 & 12.01 & 1.555 & & & \\
& & & & -125.8 & 148 & 0.000 \\
Non-victims & 75 & 39.36 & 1.061 & & & \\
\hline
\end{tabular}

$\mathrm{p}<0.01$.

As shown in the Table 2, the mean scores of the self-esteem of the victims and nonvictims of bullying were 12.01 and 39.36, respectively. The result shows that the two groups (victims and non-victims) significantly differed in self-esteem $(t=-125.8$, $\mathrm{p}<0.01)$. 
As shown in the Table 3, the mean scores of the coping skills of the victims and nonvictims of bullying were 26.67 and 86.79 , respectively. The result shows that the two groups significantly differed in coping skills $(\mathrm{t}=-175.505, \mathrm{p}<0.01)$.

Table 3. The mean, standard deviation and t-value of the coping skills between the victims and non-victims of bullying.

\begin{tabular}{lcccccc}
\hline Bullying & $\mathrm{N}$ & $\mathrm{M}$ & $\mathrm{SD}$ & $\mathrm{t}$ & $\mathrm{df}$ & $\mathrm{P}$ \\
\hline Victims & 75 & 26.67 & 2.591 & & & \\
& & & & -175.50 & 148 & 0.000 \\
Non-victims & 75 & 86.79 & 1.445 & & & \\
\hline
\end{tabular}

$\mathrm{p}<0.01$.

The results showed strong associations of bullying with self-esteem and coping skills among victims and non-victims of bullying. Correlation results (Table 1) showed that bullying has significant and negative correlations with self-esteem $(r=-0.822)$ and coping skills $(r=-0.829)$. This means increase in bullying leads to decrease in self-esteem and coping skills in students. When adolescents experience bullying they feel inferior, depression, fear and anxiety. Victims of bullying become unhappy and lonely at school, and get a fewer good friends. Such feelings cause school avoidance and poor academic performance. The consequences of such experiences are low self-esteem and negative self-concept about themselves. They cannot fight the situation as bullying also damages their coping capability. The present findings are supported by the previous studies which also found that victimization by bullying has been linked to low self-esteem and poor coping skills(12-13,16-17,34).

The result of Table 1 also showed significant positive correlation between self-esteem and coping skills $(r=0.996)$. This finding is also consistent with previous findings. When someone is confident in his own abilities he develops various coping strategies to reduce his stress. He can deal with any stressful condition with his strong coping skills. So the person whose self-esteem is high has also high coping skills ${ }^{(18)}$.

Tables 2 and 3 showed significant differences between victims and non-victims of bullying in their self-esteem ( $M=12.01$ and $M=39.36)$ and coping skills $(M=26.67$ and $M$ $=86.79)$, respectively. It is seen from the results that non-victims have higher self-esteem and coping skills than victims of bullying. It is obvious that non-victims of bullying can cope and adjust with any bad situation because of their higher self-esteem. Roberts and Andrews $^{(21)}$ also found that bullying victim has depression, low self-esteem, low coping. They also found that non-victims have higher coping skills than victims of bullying.

However, this study has some limitations. Data were collected conveniently and the sample size was small. So further research is necessary with large sample to explore more 
variables, e.g., peer relationship, school influence, family characteristics, socio-economic factors, and cultural factors. Despite the limitations the findings can help to create the awareness among general people, educators and mental health professionals about the serious damages of bullying. It can also help them to provide proper education and counseling to both victims and non-victims of bullying. Support from the family, friends and school can be useful to bully victims in reducing stress, protecting mental health and enhancing coping mechanisms.

\section{References}

1. Fenzel LM 2000. Prospective study of changes in global self-worth and strain during the transition to middle school. Journal of Early Adolescence 20(1):93-116.

2. Nansel TR, Haynie DL and Simons-Morton BG 2003. The association of bullying and victimization with middle school adjustment. Journal of Applied School Psychology 19(2): 45-61.

3. Olweus D 1993. Bullying at school: what we know and what we can do. Oxford: Blackwell.

4. Harris S and Hathorn C 2006. Texas middle school principals' perceptions of bullying on campus. NASSP Bulletin 90(1): 49-69.

5. Perren S, Dooley J, Shaw T and Cross D 2010. Bullying in school and cyberspace: association with depressive symptoms in Swiss and Australian adolescents. Child and Adolescent Psychiatry and Mental Health 4: 1-10.

6. Olweus D 1993. Victimization by peers: antecedents and long-term outcomes. In: KH Rubin and JB Asendorf (Eds.), Social withdrawal, inhibition, and shyness. pp. 315-341.

7. Boulton MJ, Smith PK and Cowie H 2010. Short-term longitudinal relationships between children's peer victimization/bullying experiences and self-perceptions evidence for reciprocity. School Psychology International 31(3): 296-311.

8. Dyer $\mathrm{K}$ and Teggart $\mathrm{T}$ 2007. Bullying experiences of child and adolescent mental health service-users: A pilot survey. Child Care in Practice 13(4): 351-365.

9. Puhl RM and Luedicke J 2012. Weight-based victimization among adolescents in the school setting: emotional reactions and coping behaviors. Journal of Youth and Adolescence 41(1): 27-40.

10. Kaltiala-Heino R, Rimpelä M, Marttunen M, Rimpelä A and Rantanen P 1999. Bullying, depression and suicidal ideation in Finnish adolescents: School survey. British Medical Journal 319: 348-351.

11. Bonanno RA and Hymel S. 2010. Beyond hurt feelings: investigating why some victims of bullying are at greater risk for suicidal ideation. Merrill-Palmer Quarterly 56: 420-440.

12. Hawker DSJ and Bulton MJ 2000. Twenty years research on peer victimization and Psychological maladjustment: A meta-analytic review of cross-sectional studies. Journal of Child Psychology and Psychiatry and Allied Disciplines 41: 441-455.

13. McDougall P, Vaillancourt $T$ and Hymel S 2009. What happens over time to those who bully and those who are victimized? In: Hymel S and Swearer S (Eds.), Bullying at school and online [Special edition of Education.com]. 
14. Smith PK, Mahdavi J, Carvalho M, Fisher S, Russell S and Tippett N 2008. Cyber bullying: its nature and impact in secondary school pupils. Journal of Child Psychology and Psychiatry 49: 376-385.

15. Sticca F and Perren S 2013. Is cyber bullying worse than traditional bullying? Examining the differential roles of medium, publicity, and anonymity for the perceived severity of bullying. Journal of Youth and Adolescence 42: 739-750.

16. Mruk C 1995. Self-Esteem: Research, Theory, and Practice. Springer.

17. Agatston PW, Kowalski R and Limber S 2007. Students' perspectives on cyber bullying. Journal of Adolescent Health 41: 59-60.

18. Abraham T 1988. Toward a self-evaluation maintenance model of social behavior. In: L. Berkowitz (Ed), Advances in Experimental Social Psychology. Academic Press. pp. 18227.

19. Machmutow K, Perren S, Sticca F and Alsaker FD 2012. Peer victimisation and depressive symptoms: can specific coping strategies buffer the negative impact of cyber victimisation? Emotional and Behavioural Difficulties 17(3-4): 403-420.

20. Sevcíkova A, Smahel D and Otavova M 2012. The perception of cyberbullying in adolescent victims. Emotional and Behavioural Difficulties 17(3-4): 319-328.

21. Roberts RE, Andrews JA, Lewinsohn PM and Hops H 1990. Assessment of depression in adolescents using the Center for Epidemiological Studies Depression Scale. Psychological Assessment: A Journal of Consulting and Clinical Psychology 2: 122-128.

22. Kanetsuna T, Smith PK and Morita Y 2006. Coping with bullying at school: children's recommended strategies and attitudes to school-based interventions in England and Japan. Aggressive Behavior 32(6): 570-580.

23. Kristensen SM and Smith PK 2003. The use of coping strategies by Danish children classed as bullies, victims, bully/victims, and not involved, in response to different (hypothetical) types of bullying. Scandinavian Journal of Psychology 44: 479-488.

24. Tenenbaum LS, Varjas K, Meyers J and Parris L 2011. Coping strategies and perceived effectiveness in fourth through eighth grade victims of bullying. School Psychology International 32(3): 263-287.

25. Cohen F and Lazarus RS 1979. Coping with the stress of illness, in Stone, C.G., Cohen, F., Adler, N.E., editors. Health psychology: A handbook. San Francisco: 217-254. CA: JosseyBass.

26. Folkman S and Lazarus RS 1980. An analysis of coping in a middle-aged community sample. Journal of Health and Social Behavior 21: 219-239.

27. Crosnoe M and Hampell DP 2009. Self-esteem and peer victimization among school children. Personality and Individual differences 18: 161-163.

28. UNICEF: $35 \%$ of students face bullying in Bangladesh. (2018, September 6). Dhaka Tribune. Retrieved from https:/wwww.dhakatribune.com/bangladesh/nation/2018/09/06/unicef-35of-students-face-bullying-in-bangladesh.

29. Sharmin N and Huque P 2015. Bullying as a predictor of emotional and social impairment in adolescents. Bangladesh Psychological Studies 25: 11-22.

30. Felix ED, Sharkey JD, Green JG, Furlong MJ and Tanigawa D 2011. Getting precise and pragmatic about the assessment of bullying: The development of the California bullying victimization scale. Aggressive Behavior 37: 234-247. 
31. Huque P 2004. The translated and adapted version of the coping scale. Dhaka University Journal of Psychology 4: 23-27.

32. IIyas QSM 2002. Self-esteem, marital adjustment, social relation and mental health as predictors of life satisfaction in Bangladesh. Bangladesh Psychological Studies 12: 77-92.

33. Rosenberg M 1965. Society and the adolescent self-image. Princeton, NJ: Princeton University Press.

34. Petrosino A, Guckenburg S, DeVoe J and Hanson T 2010. What characteristics of bullying, bullying victims, and schools are associated with increased reporting of bullying to school officials? (Issues and Answers Report, REL 2010-No. 092). Washington, DC: U.S. Department of Education, Institute of Education Sciences, National Center for Education Evaluation and Regional Assistance, Regional Educational Laboratory Northeast and Islands.

(Manuscript received on 29 August, 2018; revised on 6 November, 2018) 